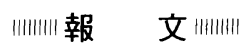

\title{
愛知県下一地域集団における血清過酸化脂質と食習慣・ 喫煙・肥満との関連に関する横断研究
}

\author{
中 村 美詠子*1, 那 須 恵 子*2, 青 木 伸 雄 ${ }^{* 1}$, 柴 田 清*1
}

${ }^{* 1}$ 浜松医科大学衛生学講座, ${ }^{* 2}$ 静岡県立大学短期大学部食物栄養学科

Cross-sectional Study on Serum Thiobarbituric Acid Reactive Substances (TBARS) in

Akabane, Japan, with Special Reference to Dietary Habits, Smoking and Obesity

\author{
Mieko Nakamura*1, Keiko Nasu*2, Nobuo Aoki*1 and Kiyoshi Shibata*1 \\ ${ }^{* 1}$ Department of Hygiene, Hamamatsu University School of Medicine ; \\ ${ }^{* 2}$ Department of Food and Nutrition Sciences, University of Shizuoka Hamamatsu College
}

In order to clarify the relation between smoking, obesity and dietary habits and thiobarbituric acid reactive substances (TBARS), we carried out a cross-sectional study in 1991 in a rural town of Akabane in Japan. The subjects were 372 males and 459 females aged $35 \sim 65$ years who participated in a health screening. The response rate was $63.3 \%$. We evaluated the complete data obtained from 297 males and 379 females. The results were as follows:

1) Serum TBARS showed substantially logarithmic-normal distribution. The arithmetic mean of TBARS was higher in men than in women in two age groups $(35 \sim 45,50 \sim 65)$, and was higher in the latter than in the former.

2) Body mass index (BMI) was related to serum TBARS both in men and women, and habitual smoking increased serum TBARS in men aged $35 \sim 45$ years.

3) Dietary habits were evaluated as the intake frequencies of foodstuffs such as meat, fish, beans, vegetables, eggs and milk in a typical week in the past year. There was observed a relation between fish intake and serum TBARS in the age group of $35 \sim 45$, and a less frequent intake of vegetables was related to high serum TBARS in women. In the multiple linear regression analysis, the standardized regression coefficients for fish and vegetable intakes in women aged $35 \sim 45$ years were 0.19 and -0.10 respectively. These findings show the importance of intake of various kinds of food.

4) Of the blood chemical parameters, triglyceride showed the strongest association with TBARS, and serum total cholesterol, uric acid and leukocyte count were also positively related with TBARS.

5) The study revealed that dietary habits, smoking, obesity and some blood chemical findings were related with serum TBARS. Further prospective studies are necessary to clarify the relationship between serum TBARS and the occurrence of cardiovascular diseases.

Jpn. J. Nutr., 51 ( 4 ) 221 233 (1993)

は じめ に

1951年にGlavindらが人の大動脈弱状硬化巣の脂質抽出物に過酸化脂質を認め, 䐖状硬化巣や石灰化の広が

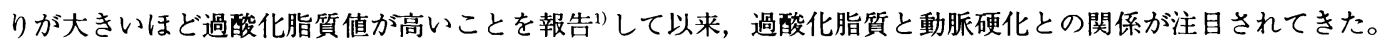

Key words : cross-sectional study, TBARS, dietary habit, smoking, obesity 横断研究，過酸化脂質，食習慣，喫煙，肥満 
過酸化脂質は，ラジカル連鎖反応により脂質が酸化されて生成する脂質過酸化物の総称である2)。現在までの 疫学調査から, 動脈硬化を基盤とした虚血性心疾患の発症には高血圧, 血清総コレステロール (Chol), 喫煙, 肥满等種々の要因がかかわっていることが明らかにされてきだ,4)。しかし，過酸化脂質については比較的多 くの臨床的, 実験的研究が行われ，動脈硬化等の疾患・病態との関連性が推測されてきたらにもかかわらず, 疫学的研究はほとんど行われていない。一時点での過酸化脂質値とその関連要因について調査した横断研究 ${ }^{6,7)}$ を散見するのみで，虚血性心疾患の危険因子の 1 つであることを評価した前向き研究8,99 は見当たらない。

また近年，虚血性心疾患を始めとした成人病予防における適切な食習慣の役割がますます重要視されてきて いる。血清過酸化脂質と食生活要因の関連については, 実験的な魚食 ${ }^{10)}$, ビ夕ミンE投与.11-13) 等により研究さ れてきたが，一般集団において過酸化脂質と食生活等との関連を検討した研究は極めて稀である。食生活要因 等と過酸化脂質との関連を明らかにすることは，循環器疾患の予防医学的観点からも重要と思われる。

そこで本研究では, 虚血性心疾患の危険因子としての血清過酸化脂質の意義を明らかにするための第一歩と して, まず横断研究8,9)により，一地域集団における血清過酸化脂質と食習慣・喫煙・肥満等との関連につい て検討し，更に虚血性心疾患の危険因子と考えられている虚血性心電図所見等との関連について検討を行った。

\section{研 究 方 法}

\section{1. 対象}

1991年 7 月に, 愛知県渥美郡赤羽根町において実施した循環器系疾患予防特別健診を受診した 35 45歳（1 墄間隔)，50，55，60，65歳の男性 372人，女性 459人の計831人（受診率：男性 $54.7 \%$ ，女性 $73.4 \%$ ）を調 查対象者とした。このうち, 採血時間が食後 5 時間未満の者 92 人及び食生活習慣についての回答が不完全であ った者63人を除いた676人（男性 297人，女性 379人）を分析対象者とした。分析対象者と分析除外者を比較 したところ，35４5歳男性では，分析対象者の平均年齢は分析除外者よりも1.2歳高く（対象者 39.6歳，除外 者 38.4歳), 血清総Chol は $13.2 \mathrm{mg} / \mathrm{dl}$ 高かった（対象者 $193.4 \mathrm{mg} / \mathrm{dl}$, 除外者 $180.2 \mathrm{mg} / \mathrm{dl}$ )。その他には, 平 均年齢，血清過酸化脂質値を始めとする血液検查所見に統計的有意差はみられなかった。35４5歳男性におけ る平均年齢の相違が, 血清総Cholに若干の影響を与えている可能性は考えられる。しかし, 血清過酸化脂質と その関連要因についての評価を行う上で，35〜45歳男性でみられた1.2歳の年齢差の及ほす影響は非常に小さ いと考えられたため, 前述の676人について分析を行った。

\section{2. 測定・判定方法}

健診時に, 血液検查, 心電図検查, 眼底検查, 理学的検查 (身長・体重測定), 問診 (喫煙・飲酒・食生活 習慣等）を実施した。問診は，健診の約 1 週間前に問診票を配布してあらかじめ記入を依頼し，不十分な点に 関しては，健診当日に栄盖士，保健婦等により確認して補完した。

血清過酸化脂質は, TBA法 (蛍光法) ${ }^{14)}$ により測定した。これは, 過酸化脂質の分解で生じるマロンダイア ルデハイド（MDA）がチオバルビッール酸（TBA）と反応して生じる赤色物質を，蛍光分析する方法である。 測定値は, 加水分解によってMDAを定量的に生成する1,1,3,3-テトラエトキシプロパンを標準物質として, $\mathrm{MDA}$ 量 $(\mathrm{nmol} / \mathrm{ml})$ として表される。測定は, 委託検査機関で行った。同検查機関では, 精度管理の一環とし

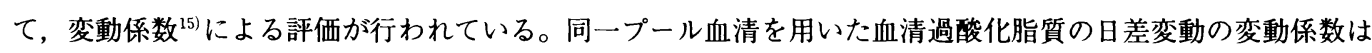
$7.2 \%$ であ（平均値 $5.0 \mathrm{nmol} / \mathrm{ml}$, 標準偏差 0.36$)^{16)}$ 。また, 本調査に先立って実施した我々の調查では, 赤 羽根町住民同一プール血清の日内変動の変動係数は $11.1 \%$ (平均値 $3.4 \mathrm{nmol} / \mathrm{ml}$, 標準偏差 $0.38, n=15$ ) で 
あった。最近の一般住民に対する調査では, 血清過酸 化脂質は対数正規分布を示している ${ }^{6,7)}$ 。今回の赤羽 根町住民での調査でも血清過酸化脂質は同様の分布を 示したため, 坂本ら ${ }^{6)}$ の報告にならい検定時には対数 変換を行った。

血清総Chol (酵素法), HDL-Chol（リンタングステ ン酸 $\mathrm{Mg}$ 沈澱法), 中性脂肪 (酵素法), 尿酸 (酵素法), 白血球数の測定は赤羽根町の委託検査機関で測定した。 安静時心電図所見はミネソタコード17)により, 眼底 所見はScheie分類 ${ }^{18)}$ により判定した。

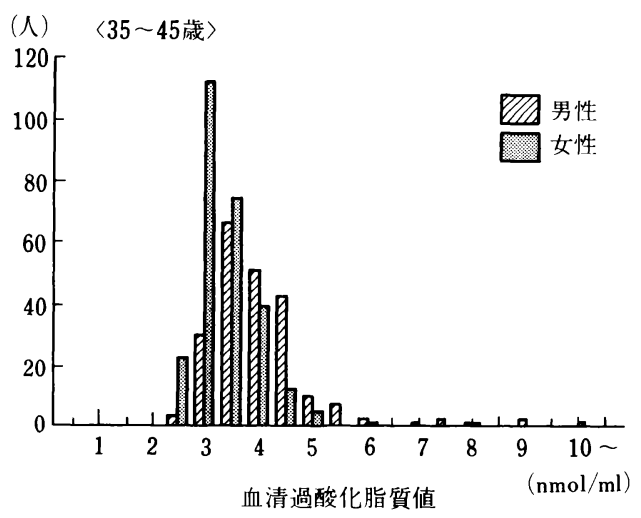

体格指数として, Body mass index (BMI) 〔体重 $(\mathrm{kg}) /$ 身長 $\left.(\mathrm{m})^{2}\right]^{19)}$ を用いた。

喫煙習慣は, 問診票により, 現在, あるいは過去の 喫煙状況, 現在の喫煙本数等を把握した。喫煙本数に かかわらず, 現在毎日煙草を吸っている, あるいは 時々吸っていると答えた者を喫煙, 過去に吸っていた と答えた者を禁煙, 煙草を吸ったことがないと答えた 者を非喫煙と区分した。

飲酒については, 現在の飲酒状況, 飲酒者の1回飲 酒量・飲酒頻度・飲酒している酒の種類等を把握した。 本研究では飲酒習慣を国民栄養調査 ${ }^{20)} に$ 準じて, 現在

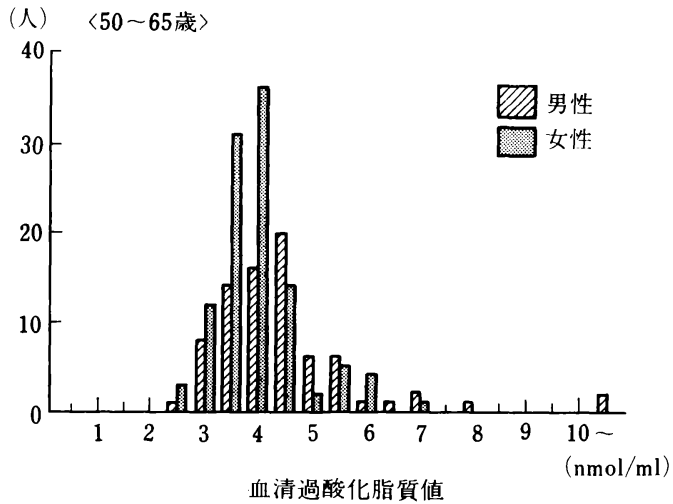

図 1 血清過酸化脂質の分布 飲酒している者のうち週 3 回以上飲酒し, かつ 1 回に 摂取するアルコール量が日本酒の 1 合相当以上の者を飲酒, それ以外の者を非飲酒と区分して評価した。

食生活習慣は, 過去 1 年間における 1 週間当たりの平均的な食品の摂取頻度について検討した。対象とした 食品・食品群は, 四訂日本食品標準成分表 ${ }^{21)}$ より, 脂質成分あるいは抗酸化成分を多く含む豚肉, 鶹肉, 牛肉, 白身の魚, 赤身の魚, 青魚, 豆腐, 油揚げ, 豆類, 鶏卵, 牛乳 (乳製品は含まず), 緑黄色野菜, 淡色野菜, いも類の14種である。摄取頻度は, ほとんど食べない, 週に 1 ほ 回, 週に 4 〜 回, 日に 1 ～回, 日に 3 回以上の 5 段階で尋ねた。各摄取頻度は, それぞれ, ほとんど食べないの 1 から, 日に 3 回以上の 5 までとし て数値化した。分析時には, 肉類 (豚肉, 鶏肉, 牛肉), 魚類 (白身の魚, 赤身の魚, 青魚), 豆類 (豆腐, 油 揚げ, 豆類), 野菜類 (緑黄色野菜, 淡色野菜, いも類), 哭鳥卵, 牛乳の大きく6 群に分類し, 肉類, 魚類, 豆 類, 野菜類については含まれる食品の各々の数值を加算した。また, 茶, ビタミン剂, ドリンク剂の攝取状況 については, “ほとんど毎日摂っている”と答えた者を常飲（常用）者，その他の者を非常飲（常用）者と区 分して検討を行った。

\section{3. 分析方法}

血清過酸化脂質の性・年齢階級別分布，算術平均値を検討した。

次に，契煙・BMI・飲酒・食生活習慣の小カテゴリー別の血清過酸化脂質の算術平均値と標準偏差を求めた。 統計学的検定は多重比較検定（ダンカン法）吕を用い, 危険率 $5 \%$ で有意差を検討した。これは, まず一元配 
表 1 年齢・身長・体重・BMI・血液検査所見の算術平均値と標準偏差

\begin{tabular}{|c|c|c|c|c|}
\hline & \multicolumn{2}{|c|}{$35 \sim 45$ 歳 } & \multicolumn{2}{|c|}{$50 \sim 65$ 歳 } \\
\hline & $\begin{array}{c}\text { 男性 } \\
(n=219)\end{array}$ & $\begin{array}{c}\text { 女性 } \\
(n=271)\end{array}$ & $\begin{array}{c}\text { 男性 } \\
(n=78)\end{array}$ & $\begin{array}{c}\text { 女性 } \\
(n=108)\end{array}$ \\
\hline 年＜wide>齢（歳） & $39.7 \pm 3.2$ & $39.9 \pm 3.1$ & $57.8 \pm 5.4$ & $57.8 \pm 5.4$ \\
\hline 長 (cm) & $166.8 \pm 5.5$ & $154.0 \pm 4.8$ & $160.9 \pm 6.4$ & $150.0 \pm 5.2$ \\
\hline 重（kg） & $64.0 \pm 9.9$ & $52.9 \pm 7.2$ & $58.8 \pm 8.9$ & $53.3 \pm 8.6$ \\
\hline B $\quad$ M $\quad$ I & $23.0 \pm 3.2$ & $22.3 \pm 2.8$ & $22.7 \pm 2.8$ & $23.7 \pm 3.5$ \\
\hline 過酸化脂質（nmol/ml） & $3.72 \pm 0.93$ & $3.11 \pm 0.74$ & $4.30 \pm 2.17$ & $3.65 \pm 0.78$ \\
\hline 総 Chol （mg/dl） & $194.0 \pm 32.2$ & $183.7 \pm 32.6$ & $186.9 \pm 30.4$ & $207.1 \pm 35.6$ \\
\hline HDL - Chol (mg/dl) & $46.5 \pm 10.7$ & $53.4 \pm 10.0$ & $46.4 \pm 12.3$ & $48.1 \pm 9.6$ \\
\hline 中性脂肪（mg/dl） & $120.0 \pm 74.6$ & $76.1 \pm 45.9$ & $120.2 \pm 80.4$ & $117.5 \pm 66.9$ \\
\hline 酸（mg/dl） & $5.77 \pm 1.36$ & $3.67 \pm 0.84$ & $5.63 \pm 1.37$ & $4.10 \pm 0.92$ \\
\hline 白 血 球 数 $\left(/ \mathrm{mm}^{3}\right)$ & $6,922 \pm 1,857$ & $5,746 \pm 1,523$ & $6,467 \pm 1,855$ & $5,568 \pm 1,287$ \\
\hline
\end{tabular}

置分散分析を行い, 全体として平均值間に差がみられるかを判断し, 更に特定のどの群とどの群の平均値に差 があるかを比較する方法である。

血清過酸化脂質と他の血液検査所見，BMI，年齢との相関を単相関分析により検討した。

また，血清過酸化脂質高値 $(\geqq 4.0 \mathrm{nmol} / \mathrm{ml})^{23)}$ の者の割合を喫煙・BMI・飲酒・食生活習慣の小カテゴリー 別に求め, 高値の者とそうでない者の間で, 血液検査所見, 虚血性心電図所見（ミネソタコード4-1 4, 5-1 $\sim 4)$, 眼底異常所見（Scheie分類高血圧性・動脈硬化性変化 2 度以上）の有所見者の割合も比較した。検定方

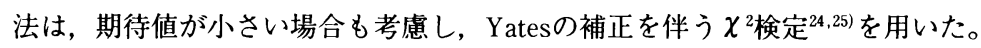

更に, 血清過酸化脂質と各食生活要因との関連を評価するために, 血清過酸化脂質を従属変数, 各食生活要

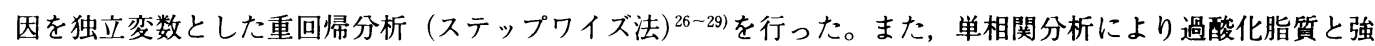
い関連を示した血液検査所見とBMI，喫煙（男性のみ）を独立変数に加えて，血清過酸化脂質と各要因との関 連についても検討した。

\section{結果}

血清過酸化脂質の性・年齢階級別の分布を図 1 に，年齢・身長・体重・BMI ・血液検查所見の算術平均値と 標準偏差を表 1 に示した。血清過酸化脂質の平均値と中央値は各々，35４5歳男性 $3.72 \cdot 3.60$, 女性 3.11 ・ $2.90 ， 50$ ６5歳男性 $4.30 \cdot 3.95$ ，女性 $3.65 \cdot 3.55$ であった。年齢層別の男女間（35４5歳 $p<0.001 ， 50$

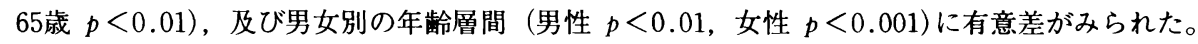

小カテゴリー別にみると，35４5歳男性で，喫煙群は非喫煙群より，BMI，肉類・魚類摃取頻度の高い群は 低い群よりも血清過酸化脂質の平均值が高かった $(p<0.05)$ 。35 45歳女性のBMI, 魚類掑取頻度（各 $p<$ 0.05), 50 65歳男女のBMIも同様の傾向（有意差なし）を示した（表 2 )。

血清総Chol，中性脂肪，尿酸，白血球数は，すべての性・年齢で血清過酸化脂質と正相関を示した。一方， HDL-Cholは，35４5歳の男性以外で逆相関を示した。BMIも35４5歳男女，50６5歳女性で血清過酸化脂質 と正相関を示した。年齢と過酸化脂質は35４5歳女性で正相関を示した。これらは，統計的に有意であった (表 3 )。

血清過酸化脂質高値の出現率は，35４5歳男性で魚類掑取頻度が高くなるほど高かった $(p<0.05)$ 。女性 
表 2 契煙・BMI・飲酒・食生活状況の小カテゴリー別血清過酸化脂質の算術平均値と標準偏差

$(\mathrm{nmol} / \mathrm{ml} ; \mathrm{M} \pm \mathrm{SD})$

\begin{tabular}{|c|c|c|c|c|c|c|c|c|}
\hline & \multicolumn{4}{|c|}{$35 \sim 45$ 歳 } & \multicolumn{4}{|c|}{50 ６5歳 } \\
\hline & $(n)$ & 男性 & (n) & 女性 & (n) & 男性 & (n) & 女性 \\
\hline \multicolumn{9}{|l|}{ 〈契煙状況〉 } \\
\hline 非喫煙 & $(41)$ & $3.38 \pm 0.50^{\mathrm{a}}$ & (263) & $3.12 \pm 0.74$ & $(17)$ & $3.64 \pm 0.92$ & (107) & $3.66 \pm 0.77$ \\
\hline 禁煙 & ( 27$)$ & $3.69 \pm 0.56$ & ( 3 ) & $2.80 \pm 0.20$ & ( 15$)$ & $4.03 \pm 0.64$ & $(1)$ & $2.30 \pm 0.00$ \\
\hline 喫煙 & $(151)$ & $3.81 \pm 1.04^{\mathrm{a}}$ & ( 5$)$ & $3.14 \pm 0.61$ & $(46)$ & $4.62 \pm 2.70$ & $(0)$ & - $\quad-$ \\
\hline \multicolumn{9}{|l|}{$\langle\mathrm{BMI}\rangle$} \\
\hline$\sim 20$ & ( 38$)$ & $3.46 \pm 0.60^{\mathrm{b}}$ & ( 52$)$ & $2.84 \pm 0.40^{\mathrm{d}, \mathrm{e}}$ & $(12)$ & $3.72 \pm 0.73$ & ( 13$)$ & $3.31 \pm 0.55$ \\
\hline $20 \sim 26$ & (148) & $3.63 \pm 0.72^{c}$ & (187) & $3.09 \pm 0.53^{\mathrm{d}, \mathrm{f}}$ & ( 58$)$ & $4.33 \pm 2.42$ & $(73)$ & $3.64 \pm 0.69$ \\
\hline $26 \sim$ & ( 33$)$ & $4.41 \pm 1.55^{\mathrm{b}, \mathrm{c}}$ & ( 32$)$ & $3.70 \pm 1.52^{\mathrm{e}, 1}$ & $(8)$ & $4.91 \pm 1.39$ & $(22)$ & $3.89 \pm 1.08$ \\
\hline \multicolumn{9}{|l|}{ 〈飲酒状況〉 } \\
\hline 非飲酒 & $(150)$ & $3.67 \pm 0.90$ & (268) & $3.11 \pm 0.74$ & $(52)$ & $4.40 \pm 2.54$ & (108) & $3.65 \pm 0.78$ \\
\hline 飲酒 & ( 69$)$ & $3.82 \pm 0.97$ & ( 3 ) & $3.17 \pm 0.40$ & $(26)$ & $4.10 \pm 1.09$ & $(0)$ & - \\
\hline \multicolumn{9}{|l|}{ 〈食生活状況〉 } \\
\hline \multicolumn{9}{|l|}{ 肉類頻度 } \\
\hline 低（ ４） & $(31)$ & $3.29 \pm 0.62^{\mathrm{g}, \mathrm{h}}$ & ( 33$)$ & $3.37 \pm 1.39$ & $(17)$ & $4.37 \pm 0.92$ & $(25)$ & $3.50 \pm 0.63$ \\
\hline 中 $(5 \sim 6)$ & $(164)$ & $3.80 \pm 0.99 \mathrm{~g}$ & (209) & $3.08 \pm 0.59$ & $(57)$ & $4.34 \pm 2.46$ & ( 68$)$ & $3.64 \pm 0.74$ \\
\hline 高（7～） & $(24)$ & $3.73 \pm 0.66^{\mathrm{h}}$ & ( 29$)$ & $3.06 \pm 0.57$ & $(4)$ & $3.38 \pm 1.33$ & ( 15$)$ & $3.97 \pm 1.09$ \\
\hline \multicolumn{9}{|l|}{ 魚類頻度 } \\
\hline 低（ ４） & ( 25$)$ & $3.24 \pm 0.57^{\mathrm{i}, \mathrm{j}}$ & ( 40$)$ & $2.92 \pm 0.30^{\mathrm{k}}$ & ( 11$)$ & $4.07 \pm 1.42$ & ( 18$)$ & $3.36 \pm 0.57$ \\
\hline 中 $(5 \sim 6)$ & $(162)$ & $3.77 \pm 0.97 \mathrm{i}$ & (195) & $3.13 \pm 0.82^{\mathrm{k}}$ & ( 49$)$ & $4.42 \pm 2.61$ & $(67)$ & $3.76 \pm 0.82$ \\
\hline 高（7～） & $(32)$ & $3.81 \pm 0.80^{\mathrm{j}}$ & ( 36$)$ & $3.22 \pm 0.55$ & ( 18$)$ & $4.09 \pm 0.85$ & ( 23$)$ & $3.57 \pm 0.75$ \\
\hline \multicolumn{9}{|l|}{ 豆類頻度*1 } \\
\hline 低（ ～6） & (103) & $3.85 \pm 1.12^{1}$ & (95) & $3.20 \pm 0.89$ & ( 9$)$ & $3.70 \pm 0.73$ & $(13)$ & $3.64 \pm 0.81$ \\
\hline 中 $(7 \sim 8)$ & $(79)$ & $3.52 \pm 0.61^{1}$ & (113) & $3.06 \pm 0.67$ & $(48)$ & $4.51 \pm 2.64$ & $(61)$ & $3.67 \pm 0.78$ \\
\hline 高（9～） & $(37)$ & $3.78 \pm 0.83$ & ( 63$)$ & $3.07 \pm 0.56$ & $(21)$ & $4.07 \pm 1.08$ & $(34)$ & $3.63 \pm 0.78$ \\
\hline \multicolumn{9}{|l|}{ 野菜類頻度*2 } \\
\hline 低（ ６） & $(57)$ & $3.78 \pm 1.00$ & ( 32$)$ & $3.36 \pm 1.30$ & $(30)$ & $4.28 \pm 1.65$ & ( 19$)$ & $3.74 \pm 0.89$ \\
\hline 中 $(7 \sim 10)$ & $(135)$ & $3.67 \pm 0.85$ & (173) & $3.10 \pm 0.64$ & $(30)$ & $4.60 \pm 3.02$ & $(39)$ & $3.63 \pm 0.65$ \\
\hline 高（11～） & ( 27$)$ & $3.85 \pm 1.14$ & ( 66$)$ & $3.02 \pm 0.57$ & ( 18$)$ & $3.81 \pm 0.77$ & $(50)$ & $3.63 \pm 0.84$ \\
\hline \multicolumn{9}{|l|}{ 牛乳頻度 } \\
\hline 低（１） & $(68)$ & $3.78 \pm 0.96$ & ( 33$)$ & $3.27 \pm 1.27$ & $(34)$ & $4.13 \pm 1.37$ & $(22)$ & $3.63 \pm 0.68$ \\
\hline 中 $(2 \sim 3)$ & $(91)$ & $3.73 \pm 0.99$ & (115) & $3.13 \pm 0.55$ & ( 28$)$ & $4.74 \pm 3.21$ & $(47)$ & $3.62 \pm 0.75$ \\
\hline 高（4～5） & $(60)$ & $3.63 \pm 0.78$ & (123) & $3.06 \pm 0.69$ & $(16)$ & $3.88 \pm 0.91$ & ( 39$)$ & $3.70 \pm 0.88$ \\
\hline \multicolumn{9}{|l|}{ 卵 頻 度 } \\
\hline 低（1～2） & ( 99$)$ & $3.61 \pm 0.93$ & ( 85$)$ & $3.25 \pm 1.00$ & $(42)$ & $4.20 \pm 1.31$ & $(45)$ & $3.62 \pm 0.86$ \\
\hline 中 ( 3$)$ & $(81)$ & $3.83 \pm 0.91$ & (136) & $3.04 \pm 0.54$ & $(24)$ & $4.90 \pm 3.39^{\mathrm{m}}$ & $(34)$ & $3.70 \pm 0.76$ \\
\hline 高（4～-5） & ( 39$)$ & $3.75 \pm 0.94$ & ( 50$)$ & $3.07 \pm 0.63$ & $(12)$ & $3.43 \pm 0.89^{\mathrm{m}}$ & ( 29$)$ & $3.64 \pm 0.69$ \\
\hline \multicolumn{9}{|l|}{ 茶 } \\
\hline 非常飲 & $(97)$ & $3.66 \pm 0.96$ & ( 97$)$ & $3.14 \pm 0.63$ & $(26)$ & $4.14 \pm 1.21$ & ( 28$)$ & $3.63 \pm 0.76$ \\
\hline 常飲 & (122) & $3.77 \pm 0.90$ & (174) & $3.10 \pm 0.79$ & $(52)$ & $4.37 \pm 2.52$ & $(80)$ & $3.76 \pm 0.79$ \\
\hline \multicolumn{9}{|l|}{ ドリンク剂 } \\
\hline 非常用 & (211) & $3.73 \pm 0.94$ & (266) & $3.12 \pm 0.74$ & $(72)$ & $4.33 \pm 2.25$ & $(103)$ & $3.66 \pm 0.78$ \\
\hline 常用 & $(8)$ & $3.30 \pm 0.24$ & ( 5$)$ & $2.82 \pm 0.27$ & $(6)$ & $3.90 \pm 0.52$ & $(5)$ & $3.56 \pm 0.76$ \\
\hline \multicolumn{9}{|l|}{ ビタミン鼡 } \\
\hline 非常用 & (213) & $3.73 \pm 0.93$ & (257) & $3.12 \pm 0.74$ & $(76)$ & $4.31 \pm 2.19$ & (104) & $3.68 \pm 0.77$ \\
\hline 常用 & $(6)$ & $3.25 \pm 0.60$ & ( 14$)$ & $2.90 \pm 0.54$ & $(2)$ & $3.95 \pm 0.50$ & $(4)$ & $2.93 \pm 0.69$ \\
\hline
\end{tabular}

*1 豆類頻度区分は $50 \sim 65$ 歳の場合は, 低 $(\sim 5)$, 中 $(6 \sim 8)$, 高 $(9 \sim)$ 。

*2 野菜類頻度区分は $50 \sim 65$ 歳の場合は, 低 $(\sim 7)$, 中 $(8 \sim 9)$, 高 $(10 \sim)$ 。

$\mathrm{a} \sim \mathrm{m}$ 同一文字間で有意差有り $(p<0.05)$ 。 
も同様の傾向を示したが, 50 65歳では男女とも一定の傾向は みられなかった（表 4 ）。

血清過酸化脂質水準別の血液 検査所見異常者頻度は，35 45 歳では男女とも，血清過酸化脂 質高值者で血清総Chol，中性脂 肪，白血球数が高い者の割合が 多く，女性で尿酸が高い者が多 かったが, HDL-Chol との関連 はみられなかった。50６5歳で は，女性の血清過酸化脂質高値 者で血清総Chol, 中性脂肪が高 い者の割合が多かった。男性で も同様の傾向がみられたが，統 計的に有意ではなかった。また， 眼底動脈硬化性所見異常者頻度 については，50－65歳男性の血 清過酸化脂質低值者でむしろ有 所見率が高かった $(p<0.05)$ が，眼底高血圧性所見，虚血性 心電図所見異常者頻度は比較的 少なく, これらと血清過酸化脂 質水準との間には有意な関連は みられなかった（表 5 )。

食生活要因を独立変数とした 重回㷌分析では, $35 \sim 45$ 歳の男 性で魚類摂取頻度が正，女性で 魚類攝取頻度が正, 野菜類摄取 頻度が負，50６5歳の女性でビ タミン剤常用が負の独立变数と して採択された（表 6 ）。しか し，いずれの重回帰分析におい ても重相関係数は比較的小さく （0.20 0.22），血清過酸化脂質 は食生活要因だけでは十分に説 明されないことが分かった。魚

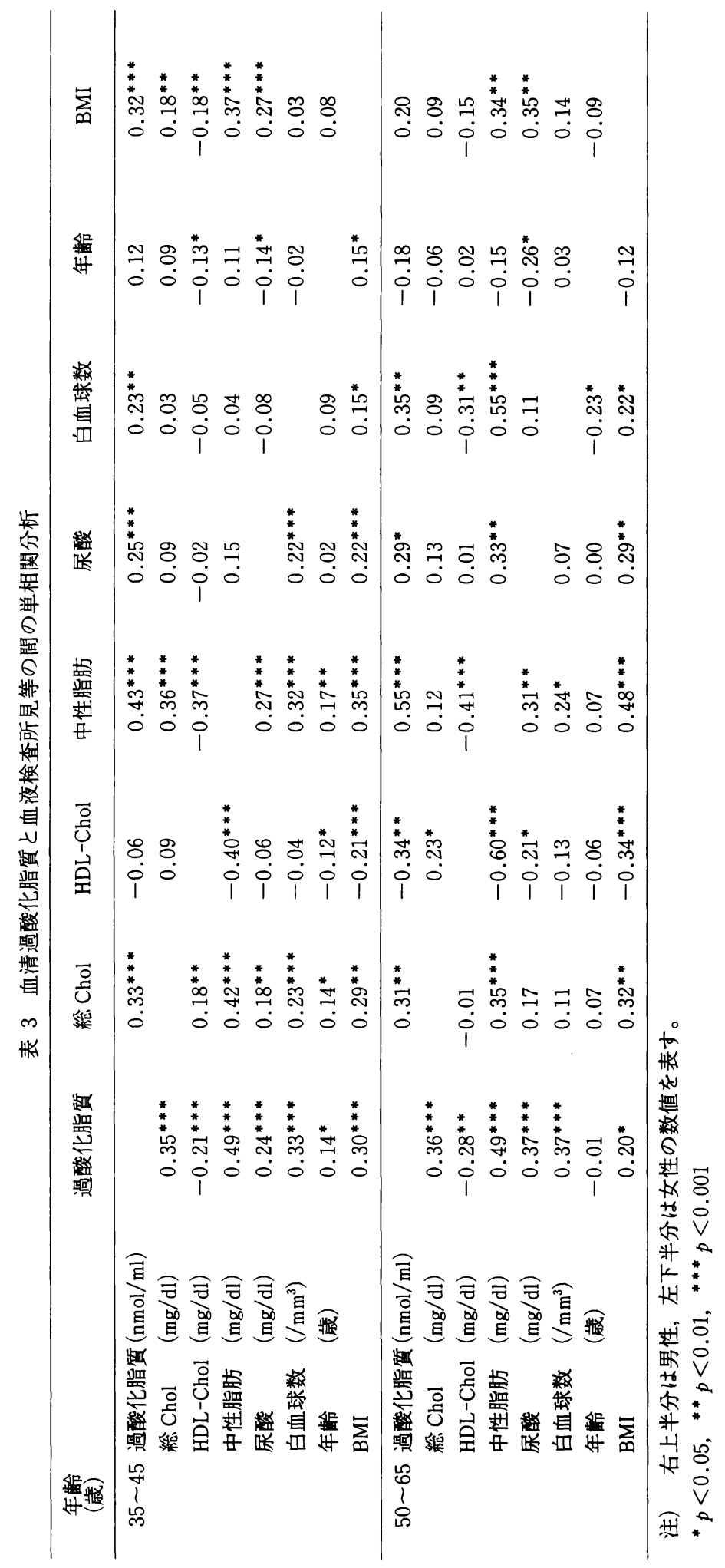

( 32 ) 
表 4 喫煙・BMI・飲酒・食生活状況の小カテゴリー別血清過酸化脂質高値者の頻度 （人）

\begin{tabular}{|c|c|c|c|c|}
\hline & \multicolumn{2}{|c|}{ 35－45歳 } & \multicolumn{2}{|c|}{$50 \sim 65$ 歳 } \\
\hline & 男性 & 女性 & 男性 & 女性 \\
\hline \multicolumn{5}{|l|}{ 〈契煙状況〉 } \\
\hline 非契煙 & $6 / 41(14.6)$ & $20 / 263(7.6)$ & $4 / 17(23.5)$ & $26 / 107(24.3)$ \\
\hline 禁 煙 & $6 / 27(22.2)$ & $0 / 3(0.0)$ & $9 / 15(60.0)$ & $0 / 0(-)$ \\
\hline 契 煙 & $56 / 151(37.1)$ & $0 / 5(0.0)$ & $26 / 46(56.5)$ & $0 / 1(0.0)$ \\
\hline \multicolumn{5}{|l|}{$\langle\mathrm{BMI}\rangle$} \\
\hline$\sim 20$ & $10 / 38(26.3)$ & $1 / 52(1.9)$ & $5 / 12(41.7)$ & $1 / 13(7.7)$ \\
\hline $20 \sim 26$ & $40 / 148(27.0)$ & $11 / 187(5.9)$ & $29 / 58(50.0)$ & $18 / 73(24.7)$ \\
\hline $26 \sim$ & $18 / 33(54.5)$ & $8 / 32(25.0)$ & $5 / 8(62.5)$ & $7 / 22(31.8)$ \\
\hline \multicolumn{5}{|l|}{ 〈飲酒状況〉 } \\
\hline 非飲酒 & $42 / 150(28.0)$ & $20 / 268(7.5)$ & $25 / 52(48.1)$ & $26 / 108(24.1)$ \\
\hline 飲 酒 & $26 / 69(37.7)$ & $0 / 3(0.0)$ & $14 / 26(53.8)$ & $0 / 0(-)$ \\
\hline \multicolumn{5}{|l|}{ 〈食生活状況〉 } \\
\hline \multicolumn{5}{|l|}{ 肉類頻度 } \\
\hline 低 $(-4)$ & $6 / 31(19.4)$ & $5 / 33(15.2)$ & $12 / 17(70.6)$ & $8 / 25(32.0)$ \\
\hline 中 $(5 \sim 6)$ & $53 / 164(32.3)$ & $13 / 209(6.2)$ & $26 / 57(45.6)$ & $12 / 68(17.6)$ \\
\hline 高（7～） & $9 / 24(37.5)$ & $2 / 29(6.9)$ & $1 / 4(25.0)$ & $6 / 15(40.0)$ \\
\hline \multicolumn{5}{|l|}{ 魚類頻度 } \\
\hline 低（－4） & $3 / 25(12.0)^{*}$ & $0 / 40(0.0)$ & $6 / 11(54.5)$ & $3 / 18(16.7)$ \\
\hline 中 $(5 \sim 6)$ & $50 / 162(30.9)$ & $16 / 195(8.2)$ & $23 / 49(46.9)$ & $18 / 67(26.9)$ \\
\hline 高（7～） & $15 / 32(46.9)$ & $4 / 36(11.1)$ & $10 / 18(55.6)$ & $5 / 23(21.7)$ \\
\hline \multicolumn{5}{|l|}{ 豆類頻度 ${ }^{* 1}$} \\
\hline 低（～６） & $37 / 103(35.9)^{*}$ & $7 / 95(7.4)$ & $4 / 9(44.4)$ & $3 / 13(23.1)$ \\
\hline 中 $(7 \sim 8)$ & $15 / 79(19.0)$ & $8 / 113(7.1)$ & $26 / 48(54.2)$ & $16 / 61(26.2)$ \\
\hline 高（9～） & $16 / 37(43.2)$ & $5 / 63(7.9)$ & $9 / 21(42.9)$ & $7 / 34(20.6)$ \\
\hline \multicolumn{5}{|l|}{ 野菜類頻度*2 } \\
\hline 低 $(\sim 6)$ & $19 / 57(33.3)$ & $3 / 32(9.4)$ & $15 / 30(50.0)$ & $5 / 19(26.3)$ \\
\hline 中 $(7 \sim 10)$ & $39 / 135(28.9)$ & $11 / 173(6.4)$ & $15 / 30(50.0)$ & $9 / 39(23.1)$ \\
\hline 高（11～） & $10 / 27(37.0)$ & $6 / 66(9.1)$ & $9 / 18(50.0)$ & $12 / 50(24.0)$ \\
\hline \multicolumn{5}{|l|}{ 牛乳頻度 } \\
\hline 低（1） & $24 / 68(35.3)$ & $3 / 33(9.1)$ & $19 / 34(55.9)$ & $5 / 22(22.7)$ \\
\hline 中 $(2 \sim 3)$ & $29 / 91(31.9)$ & $8 / 115(7.0)$ & $13 / 28(46.4)$ & $13 / 47(27.7)$ \\
\hline 高（4～5） & $15 / 60(25.0)$ & $9 / 123(7.3)$ & $7 / 16(43.8)$ & $8 / 39(20.5)$ \\
\hline \multicolumn{5}{|l|}{ 卵頻度 } \\
\hline 低 (1～2) & $27 / 99(27.3)$ & $7 / 85(8.2)$ & $23 / 42(54.8)^{* *}$ & $10 / 45(22.2)$ \\
\hline 中 (3) & $28 / 81(34.6)$ & $9 / 136(6.6)$ & $15 / 24(62.5)$ & $10 / 34(29.4)$ \\
\hline 高 (4～5) & $13 / 39(33.3)$ & $4 / 50(8.0)$ & $1 / 12(8.3)$ & $6 / 29(20.7)$ \\
\hline \multicolumn{5}{|l|}{ 茶 } \\
\hline 非常飲 & $27 / 97(27.8)$ & $9 / 97(9.3)$ & $13 / 26(50.0)$ & $7 / 28(25.0)$ \\
\hline 常 飲 & $41 / 122(33.6)$ & $11 / 174(6.3)$ & $26 / 52(50.0)$ & $19 / 80(23.8)$ \\
\hline \multicolumn{5}{|l|}{ ドリンク剤 } \\
\hline 非常用 & $68 / 211(32.2)$ & $20 / 266(7.5)$ & $37 / 72(51.4)$ & $24 / 103(23.3)$ \\
\hline 常 用 & $0 / 8(0.0)$ & $0 / 5(0.0)$ & $2 / 6(33.3)$ & $2 / 5(40.0)$ \\
\hline \multicolumn{5}{|l|}{ ビタミン剂 } \\
\hline 非常用 & $68 / 213(31.9)$ & $19 / 257(7.4)$ & $38 / 76(50.0)$ & $26 / 104(25.0)$ \\
\hline 常 用 & $0 / 6(0.0)$ & $1 / 14(7.1)$ & $1 / 2(50.0)$ & $0 / 4(0.0)$ \\
\hline
\end{tabular}

*1 豆類頻度区分は $50 \sim 65$ 歳の場合は, 低 $(\sim 5)$, 中 (6 8), 高 $(9 \sim)$ 。

*2 野菜類頻度区分は50 65歳の場合は, 低 $(\sim 7)$, 中 $(8 \sim 9)$, 高 $(10 \sim)$ 。

${ }^{*} p<0.05,{ }^{* *} p<0.01$

( )内は\%。 
類・野菜類摂取頻度, ビタミン剂常用, 血清総 $\mathrm{Chol}$, 中性脂肪, 尿酸, 白血球数, BMI, 喫煙習慣（男性のみ）を独立変数 とした重回㷌分析では，すべての性・年 齢別群で血清過酸化脂質の正の関連要因 として中性脂肪と総Cholが採択された。 中性脂肪の標準偏回㷌係数は, 0.28 0.42 であり, 取り上げた独立変数の中で 最大であった。また，35４5歳の男女と も血清過酸化脂質は，契煙を考慮しても 白血球数と正の関連がみられた。35〜45 歳男性では, 喫煙とも正の関連がみられ た。また，35４5歳男女では血清過酸化 脂質はBMI, 魚類摃取頻度と正の関連を 示した。女性の野菜類摄取頻度と $35 \sim 45$ 歳女性, 50－65歳男性のHDL-Cholは負 の関連を示した。尿酸と正の関連を示し たのは35～45歳男性，50－65歳女性であ るが，その標準偏回㷌係数はそれぞれ， $0.19 ， 0.23$ と比較的大きかった。

\section{考察}

生体内過酸化脂質の測定法にはTBA 法 (比色法, 蛍光法), 化学発光-HPLC 法, 呼気分析法, 蛍光分析法などがある。 各々の測定法により，分析の対象となる 成分や特徽が異なっている。例えば，化 学発光-HPLC法は, 酸化の第一次生成物 であるハイドロパーオキサイドを分析対 象としているのに対し, TBA法は, 二 次酸化産物であるマロンダイアルデハイ ドを測定している。前者は, 生体内抗酸 化物質を分離してその影響を取り除いて いる ${ }^{30)}$ のに対し, 後者は, 共存する脂質, 金属などの酸化促進要因, 生体内抗酸化 要因の影響を受けた総合的な数值になっ ている可能性が大きいとされている311。

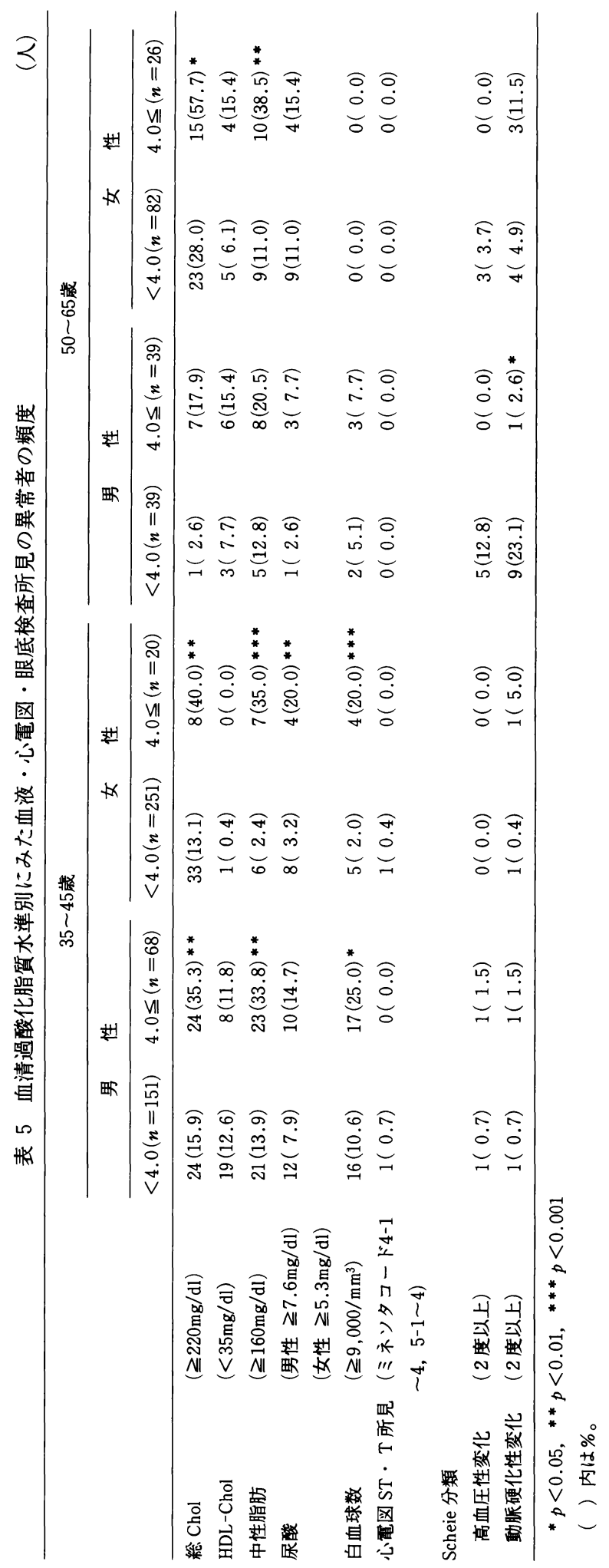


現在, 1 つの分析法で脂質の酸化 過程のすべての段階を完全に評価 する方法はない ${ }^{32)}$ 。しかし, TBA 法は同一の実験条件，類似した試 料間での相対的な比較には有用と 考えられており ${ }^{32)}$, 更に微量の試 料で測定が可能であること，操作 が簡単で短時間で測定できること は, 多人数の一般集団を対象とす る調査では長所といえる。また， これまでの報告においても TBA 法が多く用いられている6,7,11 13) ことから, 本研究においても TBA法を用いて血清過酸化脂質 を評価した。

35 - 45歳, 50 - 65歳の両年齢層 で血清過酸化脂質は女性より男性 で高値を示した。また, 非契煙者 のみの分析では35〜 45歳の年齢層 で男性が女性より高値を示した ( $p<0.01)$ が, 50〜65歳ではこの 性差はみられなかった。血清過酸 化脂質の性差はみられないという 報告 ${ }^{33)}$ もるが, 中年期以前の年 齢でみられるとする報告が比較的 多い。酸化促進要因と考えられる 喫煙を除いた分析でも性差が観察 されたことは，女性で何らかの抗 酸化的要因が働いている可能性が 強い。抗酸化物質として，まず, 黄体（女性）ホルモンであるエス トロゲンとその代謝産物が考えら れる ${ }^{34)}$ 。黄体ホルモンの濃度は,
表 6 異なる独立変数の組合わせによる血清過酸化脂質 を従属変数とした重回㷌分析

\begin{tabular}{|c|c|c|c|c|c|}
\hline & $\begin{array}{l}\text { 年齢 } \\
\text { (歳) }\end{array}$ & 性別 & 独立変数*1 & $\begin{array}{l}\text { 標準偏回 } \\
\text { 嵪 係 数 }\end{array}$ & $\begin{array}{l}\text { 重相関 } \\
\text { 係 数 }\end{array}$ \\
\hline \multirow[t]{4}{*}{$\langle A\rangle$} & $35 \sim 45$ & 男性 & 魚類頻度 & $0.20^{* *}$ & 0.20 \\
\hline & & 女性 & $\begin{array}{l}\text { 魚類頻度 } \\
\text { 野菜類頻度 }\end{array}$ & $\begin{aligned} & 0.20^{* *} \\
- & 0.13^{*}\end{aligned}$ & 0.22 \\
\hline & $50 \sim 65$ & 男性 & 無し & & \\
\hline & & 女性 & ビタミン剤常用 & $-0.22^{*}$ & 0.22 \\
\hline \multirow[t]{4}{*}{$\langle\mathrm{B}\rangle$} & $35 \sim 45$ & 男性 & $\begin{array}{l}\text { 中性脂肪 } \\
\text { 尿酸 } \\
\text { 喫煙 } \\
\text { 白血球数 } \\
\text { 魚類頻度 } \\
\text { BMI } \\
\text { 総 Chol }\end{array}$ & $\begin{array}{l}0.28^{* * *} \\
0.19^{* * *} \\
0.18^{* *} \\
0.16^{* *} \\
0.15^{* *} \\
0.15^{*} \\
0.14^{*}\end{array}$ & 0.60 \\
\hline & & 女性 & $\begin{array}{l}\text { 中性脂肪 } \\
\text { 魚類頻度 } \\
\text { 総 Chol } \\
\text { 白血球数 } \\
\text { BMI } \\
\text { 野菜類頻度 } \\
\text { HDL-Chol }\end{array}$ & $\begin{array}{c}0.28^{* * *} \\
0.19^{* * *} \\
0.18^{* *} \\
0.16^{* *} \\
0.10^{\#} \\
-0.10^{*} \\
-0.10^{\#}\end{array}$ & 0.59 \\
\hline & $50 \sim 65$ & 男性 & $\begin{array}{l}\text { 中性脂肪 } \\
\text { 総 Chol } \\
\text { HDL-Chol }\end{array}$ & $\begin{array}{c}0.42^{* * *} \\
0.32^{* *} \\
-0.24^{*}\end{array}$ & 0.64 \\
\hline & & 女性 & $\begin{array}{l}\text { 中性脂肪 } \\
\text { 白血球数 } \\
\text { 尿酸 } \\
\text { 総 Chol } \\
\text { 野菜類頻度 }\end{array}$ & $\begin{array}{l}0.29^{* *} \\
0.27^{* * *} \\
0.23^{* *} \\
0.21^{*} \\
-0.15^{\#}\end{array}$ & 0.64 \\
\hline
\end{tabular}

*1〈A〉は肉類 · 魚類 - 豆類 ·野菜類・牛乳・卵頻度, 茶・ビ夕ミン 剤・ドリンク剂常用を用いた時に重回帰式に取り込まれた変数。 〈B〉は総 Chol, HDL-Chol, 中性脂肪, 尿酸, 白血球数, 魚類 - 野 菜類頻度, ビタミン剂常用, BMI, 契煙（男性のみ, 非喫煙 0 , 禁煙 1, 契煙 2とする）を用いた時に重回㷌式に取り込まれた変 数。

\# $p<0.10,{ }^{*} p<0.05,{ }^{* *} p<0.01,{ }^{* * *} p<0.001$ 重回帰分析はステップワイズ法による。

月経のある女性で最も高く, 男性がこれに続き, 閉経後女性は男性より更に低い35)。女性でも黄体期, 妊娠に より更に上昇するが，その濃度から考えて $\alpha$-トコフェロールに勝る抗酸化物質であるとはいえないようであ る $^{34)}$ 。また, $\alpha$-トコフェロールを始め, アスコルビン酸, $\beta$-カロテンなどのビタミン類の影響も考えられる。 血中ビ夕ミン濃度には食物からのビタミン摄取, 他の食品成分 ${ }^{36)}$, 喫煙等の要因が関与しており, これらを評 
価するために更に詳細な検討が望まれる。

今回の対象者中，契煙習慣のある者は男性 $66.3 \%$, 女性 $1.6 \%$ あったので，喫煙は主に男性について評 価した。血清過酸化脂質の平均値は，35４5歳男性で，喫煙者は非㿴煙者に比べて高く $(p<0.05)$ ，また， 禁煙者も非契煙者に比べやや高い傾向を示し（有意差なし），哝煙習慣と血清過酸化脂質との関連が推測され た。喫煙習慣と血清過酸化脂質高値との関連は, BMI, 血液検查所見, 魚類・野菜類摂取頻度等を考虑しても 有意であった。煙草煙中には一息につき約 $10^{14}$ のラジカルが含まれるとされる ${ }^{37}$ 。二酸化窒素等のラジカルは, 試験管内あるいは生体内で膜脂質の多価不飽和脂肪酸と反応して過酸化脂質を生成することが知られており ${ }^{38)}$, 本研究の結果と一致する。しかし, 坂本ら ${ }^{6)}$ の横断研究では喫煙による過酸化脂質の有意な上昇は観察されて

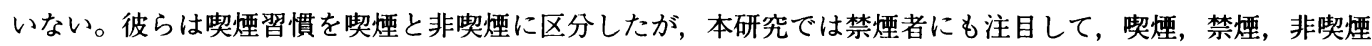
の3つに区分した点で異なっている。

白血球数は哭煙により上昇することが知られているが，また，白血球数は虚血性心疾患の発症と関連してい るという報告もある ${ }^{39.40)}$ 。本調查では，喫煙習慣を考虑しても白血球数は血清過酸化脂質と正の関連を示した。 白血球の大部分を占める好中球は，異物を貪食する際に細胞外 $\mathrm{O}_{2}-$ (スーパーオキサイドラジカル）をつくる ことから, 白血球数の増加がその貪食作用を介して血清中の脂質の酸化に関与している可能性がある。 本研究では，体脂肪量との相関が高いとされる BMI ${ }^{19}$ を肥満の指標として用いた。35〜45歳では, 食生活・ 喫煙習慣を考慮してもBMI と血清過酸化脂質との正の関連がみられた。また，中性脂肪はすべての性・年齢群 で正の関連を示した。血清脂質の酸化を考える時, 脂質の量の他に, その成分組成が問題となる。体内・血液 中の脂質の成分組成は食事中脂質組成の影響を受ける。今回, 脂質の成分組成については調查しなかったが, 脂質の酸化を更に詳細に評価するためには，量的な側面と質的な側面の両面からのアプローチが望まれる。

食物中には，脂質，酸化に促進的に働くと考えられる金属等の他，消化・吸収過程，あるいは生体内で抗酸 化的に㗢く成分も含んでいる ${ }^{41)}$ 。脂質過酸化の過程にはいくつかの因子が関与しており, 食品の抗酸化性も複 数成分による相乗効果が大きいといわれる ${ }^{42)}$ 。

今回，食生活と血清過酸化脂質との関連を検討するために，食品の摄取頻度と茶，ビタミン剂，ドリンク剤 の摄取状況を調査した。肉類，魚類，豆類・豆製品，牛乳，鶏卵は主に脂質の供給源，野菜類，いも類，茶， ビタミン剤，ドリンク剂は主に抗酸化成分の供給源と考えられる。これらの食生活要因のうち魚類摂取頻度が, 35〜45歳で血清過酸化脂質と正の関連を示した。また，食生活要因のみを独立変数とした重回㷌分析では，35 ～45歳女性で野菜類攝取頻度，50～65歳女性でビタミン剤常用が負の関連を示した。魚類・野菜類摃取頻度は, 血液検査所見, BMI等を考虑しても過酸化脂質と有意に関連していた。魚類の脂質成分は多価不飽和脂肪酸が 多く含まれている点が特徵的であり, 抗血栓作用等の利点が強調される一方で, 酸化の標的にもなりやすいこ

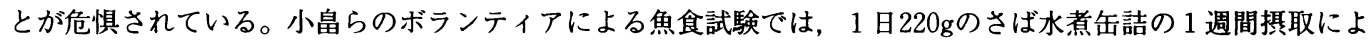
る血清過酸化脂質の上昇を認めている ${ }^{10)}$ 。国民栄養調査による日本人の 1 日の魚介類掑取量は約 $100 \mathrm{~g}^{20)}$ であり, 1 日 $220 \mathrm{~g}$ というのは日本人の平均的摄取量に比べ多めの量といえよう。本調査では摄取量については特に考慮 しなかったが，日常的な㠌取量の場合でも35 45歳では魚類高頻度摄取と血清過酸化脂質高値とが関連してい ることが明らかにされた。

また, 野菜類高頻度摄取, ビタミン剂常用と血清過酸化脂質との負の関連は, 食生活による抗酸化効果を推 測させ興味深い。35 45歳女性における重回㷌分析では, 魚類摂取頻度の標準偏回帰係数は 0.19 , 野菜類囹取 頻度のそれはー0.10であり, バランスのとれた食生活の場合, 食生活要因は血清過酸化脂質の上昇に大きな影 
響を与えない。しかし，偏った食生活（例えば魚類を頻繁に摂取し，それに見合った野菜類が摄取されていな い場合等）は，血清過酸化脂質を增加させる要因となる。今回の調査では，野菜類，ビタミン類と血清過酸化 脂質との負の関連は女性のみに観察された。

虚血性心疾患や脳卒中の発症に及ほす過酸化脂質の影響についての検討は，今後の課題である。

\section{要 約}

1991年の愛知県赤羽根町における循環器系疾患予防特別健診に参加した35～65歳の男性 372 人，女性 459 人 を対象とした。健診の受診率は，男性 $54.7 \%$, 女性 $73.4 \%$ あっった。このうち, 完全なデー夕の得られた男 性 297 人，女性 379 人を分析対象者として，血清過酸化脂質とその関連要因に関する横断研究を実施した。

1）血清過酸化脂質は対数正規に近い分布を示し，男性は女性より，50～65歳は35～45歳よりもその平均値 が高かった。

2）血清過酸化脂質は男女ともBMIが大きいほど高く，また，喫煙習慣は35４5歳男性で過酸化脂質を上昇 させた。食生活習慣は, 最近 1 年間の平均的な食品（肉類, 魚類, 豆類, 野菜類, 牛乳, 卵) の摂取頻度とし て評価した。35〜45歳で過酸化脂質は魚類摂取頻度と正の関連を示した他，女性では野菜類摄取頻度，ビタミ ン剤常用が少ないと過酸化脂質は高い傾向を示した。過酸化脂質を従属変数, 食品掑取頻度, 喫煙, BMI, 血 液検查所見等を独立变数とした重回帰分析を行ったところ，35〜 45歳の女性の魚類掑取頻度の標準偏回帰係数 は0.19, 野菜類掑取頻度のそれは一0.10であった。血清過酸化脂質に食生活要因が関与していることが確認さ れ，また，食事のバランスの重要性が認められた。

3）血液検查所見のうち, 過酸化脂質と最も関連の強かったものは中性脂肪であり，また，血清総Chol，尿 酸, 白血球数と関連していた。

4）過酸化脂質の関連要因として食生活習慣，喫煙，肥満が意義をもつことが明らかになった。今後更に前 向き研究等により，過酸化脂質と虚血性心疾患の発症との関連が明らかにされることが期待される。

\section{文献}

1) Glavind, J., Hartmann, S., Clemmesen, J., Jessen, K. E. and Dam, H. : Studies on the role of lipoperoxides in human pathology. II. The presence of peroxidized lipids in the atherosclerotic aorta, Acta Pathol. Microb. Scand, 30, 1 6 (1951)

2）荻原 享, 保田 浩, 美濃 真：過酸化脂質の測定法, 臨床検査，33，262２67 (1989)

3）上田一雄：久山町住民にみられた虚血性心疾患とその危険因子の時代的動向，日循協誌，26，155１60 (1992)

4）小町喜男：地域・職種による栄養掑取の差異と脳卒中・虚血性心疾患との関連に関する研究（昭和58年 度厚生省循環器病研究委託費による研究), 日循協誌, 19, 49 61 (1984)

5）吉川敏一：過酸化脂質と生体/内山 充, 松尾光芳, 輅峨井勝編, pp.289 313 (1985) 学会出版セン 夕一, 東京

6）坂本峰至，中野篤浩，金城芳秀，若宮純司，藤崎 正，東 博文，北野隆雄，二塚 信：一般住民健診 における過酸化脂質値（血槳TBA値）についての断面研究，日公衛誌，39，399４09（1992）

7）井奈波良一，中村秀喜：一山村住民の血清過酸化脂質，公衆衛生，50，275～278（1986）

8）田中平三：疫学入門演習, pp.3 15（1989）南山堂, 東京

9）吉村健清：新しい疫学/重松逸造，柳川 洋監修, pp.64 70（1991）日本公衆衛生協会, 東京 
10）小畠義樹，斉藤衛郎，黑田圭一，小林修平，印南 敏：中高年者の血清脂質と過酸化脂質の濃度におよ ほす魚食の影響，日栄食糧会誌，40，103１10（1987）

11) Cordova, C., Musca, A., Violi, F., Alessandri, C., Ghiselli, A., Iuliano, L. and Balsano, F. : Influence of vitamin E on plasma malondialdehyde-like material in man, Thromb. Haemostas., 51, 347 348 (1984)

12) Szczeklik, A., Gryglewski, R. J., Domagala, B., Dworski, R. and Basista, M. : Dietary supplementation with vitamin $\mathrm{E}$ in hyperlipoproteinemias : Effects on plasma lipid peroxides, antioxidant activity, prostacyclin generation and platelet aggregability, Thromb Haemostas., 54, 425 430 (1985)

13) Schafer, L. and Thorling, E. B. : Lipid peroxidation and antioxidant supplementation in old age, Scand. J. Clin. Lab. Invest., 50, 69 75 (1990)

14）島崎弘幸：過酸化脂質実験法/金田尚志，植田伸夫編，pp.80－89（1983）医菌薬出版，東京

15）丹後俊郎：臨床検查の統計学, pp.67 68（1986）朝倉書店, 東京

16）石井 暢監修：検査值の経時的変動，p.207（1990）エスアールエル，東京

17) Prineas, R. J., Crow, R. S. and Blackburn, H. : The Minnesota Code. Manual of Electrocardiographic Findings, pp. 60 97 (1982) John Wright • PSG Inc, London

18) Scheie, H. G. : Evaluation of ophthalmoscopic changes of hypertension and arteriolar sclerosis, Arch. Ophthalmol., 49, 117 138 (1953)

19) Keys, A., Fidanza, F., Karvonen, M. J., Kimura, N. and Taylor, L. : Indices of relative weight and obesity, J. Chron. Dis., 25, 329 343 (1972)

20）厚生省保健医療局健康增進栄養課監修：国民栄養の現状 平成 2 年調査成績, pp.3 62（1992）第一出 版, 東京

21）科学技術庁資源調査会編：四訂日本食品標準成分表（1982）大藏省印刷局，東京

22）石居 進：生物統計学入門, pp.176 181（1975）培風館, 東京

23）八木国雄：過酸化脂質は老化を促進するか，基礎老化研究，9，31３9（1986）

24） Fisher, R. A. : Statistical Methods for Research Workers （1963）/遠藤健児，鍋谷清治訳：研究者のた めの統計的方法, pp.73 77 (1970) 森北出版, 東京

25) Cochran, W. G. : Some methods for strengthening the common $\chi^{2}$ tests, Biometrics, 10, 417 451 (1954)

26）富永鿆民，他：臨床のための疫学入門，pp.51～56（1989） 日本医事新報社，東京

27）杉山高一：多変量デー夕解析入門, pp.104 136（1983）朝倉書店, 東京

28） 久米 均: 多変量解析法, pp.25 49（1971） 日科技連出版社, 東京

29) Dixon, W. J. ed. : BMDP Statistical Software, pp. $264 \sim 277$ (1985) University of California Press, Los Angeles

30) Yamamoto, Y. and Ames, B. N. : Detection of lipid hydroperoxides and hydrogen peroxide at picamole levels by an HPLC and isoluminol chemiluminescence assay, Free Radic. Boil. Med., 3, 359 361 (1987)

31）内山 充：過酸化脂質と生体/内山 充, 松尾光芳, 聯峨井勝編, pp.3 11（1985）学会出版センター, 東京

32）寺尾純二：過酸化脂質の測定, The Lipid, 3，236２43（1992）

33）佐藤政男：過酸化脂質と生体/内山 充, 松尾光芳, 痁峨井勝編, pp.171 189（1985）学会出版七ン 夕一, 東京

34）中野 稔：エストロゲンの抗酸化能, 活性酸素フリーラジカル, 2, 217〜223（1991）

35）三宅 㑆，谷澤 修：エストロジェン，内科，61，1362（1988）

36）五十嵐脩：ビタミンEの栄養状態に及ほす食事性因子の影響，日栄食糧会誌，44，335～343（1991）

37）吉川敏一, 谷川 徹, 近藤元治：喫煙による気道障害と活性酸素, 活性酸素フリーラジカル, 3, 163 171 (1992)

38） Halliwell, B. and Gutteridge, J. M. C. : Free Radicals in Biology and Medicine（1985）/松尾光芳, 㟍峨井 勝, 吉川敏一訳：フリーラジカルと生体, pp.237〜240（1988）学会出版センター, 東京 
39) Friedman, G. D., Klatsky, A. L. and Siegelaub, A. B. : The leukocyte count as a predictor of myocardial infarction, N. Engl. J. Med., 290, 1275 1278 (1974)

40) Yarnell, J. W. G., Baker, I. A., Sweetnam, P. M., Bainton, D., O’Brien, J. R., Whitehead, P. J. and Elwood, P. C. : Fibrinogen, viscosity, and white blood cell count are major risk factors for ischemic heart disease, Circulation, 83, 836 -844 (1991)

41）寺尾純二：過酸化脂質と食品, 油化学, 37, 878 884（1988）

42）並木満夫：食品系の天然抗酸化物, 活性酸素フリーラジカル, 2, 173〜181（1991）

(受付：平成 4 年11月14日) 